\title{
INCIDENCE OF FRUIT ROT ON JAPANESE QUINCE (CHAENOMELES JAPONICA) IN LATVIA
}

\author{
Inta Jakobija ${ }^{1,2}$, Biruta Bankina ${ }^{1}$ \\ ${ }^{1}$ Latvia University of Life Sciences and Technologies, Latvia \\ ${ }^{2}$ Latvian Plant Protection Research Centre, Latvia \\ inta.jakobija@laapc.lv
}

\begin{abstract}
Japanese quince (Chaenomeles japonica) is cultivated as a fruit crop because its fruit possesses valuable properties. The total area of Japanese quince in Latvia is continuously increasing; therefore, fruit rot can become an important reason of yield loss. The aim of this study was to clarify the fruit rot incidence in Japanese quince plantations in Latvia and explore the influencing factors of rot development in the year 2017. The evaluation of fruit rot was carried out during the fruit development in eight places of different regions of Latvia where Japanese quince is grown commercially. Three plantations of different Japanese quince cultivars in Dobele and seven plantations where Japanese quince is grown from seedlings were observed. Fruit rot incidence among plantations had no significant differences. Statistically significant differences in fruit rot incidence depending on quince growth stage $(p<0.05)$ were found. Significant differences in fruit rot incidence were found between cultivars in Dobele.
\end{abstract}

Key words: fruit crop, seedlings, growth stage, plantation, fungal diseases, evaluation.

\section{Introduction}

Japanese quince (Chaenomeles japonica (Thumb.) Lindley ex Spach) is one of the four species in the genus Chaenomeles Lindl. belonging to the subfamily Maloidae of the family Rosaceae (Weber, 1964; Phipps et al., 1990; Ling-Ti et al., 2003). The natural growth area of Japanese quince is the central and southern part of Japan (Weber, 1964). Japanese quince (hereinafter quince) is cultivated as an ornamental crop in China (Ling-Ti et al., 2003) and in many other countries of the world. Quince as a fruit crop is cultivated in Latvia and Lithuania (Mierina et al., 2011), several regions of Russia (Fedulova, Skripnikova, \& Mezhenskiū, 2009; Федулова, Куклина, \& Каштанова, 2017), Poland (Nahorska, Dzwoniarska, \& Thiem, 2014), Belarus (Panteev, Batchilo, \& Grakovich, 1995), Sweden (Rumpunen, 2002), and in southern Finland (Kauppinen \& Weckman, 2002). According to the information of Ministry of Agriculture of the Republic of Latvia (2016), the total area of quince plantations was 102 ha in 2013, 116 ha in 2014, and 200 ha in 2015; and this increase still continues.

Mierina et al. (2011) found that quince fruit was the major source of minerals in comparison with other pome fruits. Results of the analysis conducted by Baranowska-Bosiacka et al. (2017) showed that quince fruit was rich in valuable nutrients, ascorbic acid, phenols, and fibre and had a low oxalate content. Quince fruits are considered a perspective source for use in medicine (Nahorska, Dzwoniarska, \& Thiem, 2014; Banaś \& Korus, 2016), cosmetics and food industry (Nahorska, Dzwoniarska, \& Thiem, 2014).

Kaufmane et al. (2013) quoting Tics (1992) reported that the first studies of breeding quince as a fruit crop in Latvia were carried out in the 1950s. Several investigations in $C$. japonica growing and breeding were performed in $1999-2001$ in cooperation with scientists from Latvia, Sweden, Finland, Lithuania, France, and Spain (Kaufmane et al., 2013). However, few studies of fungal diseases in quince are performed in Europe, and even less in Latvia. From 1998 to 2001, studies of pests and diseases were performed in Sweden, including also a few samples of quince leaves collected in Dobele, Latvia (Norin \& Rumpunen, 2003). From 2009 to 2011 the evaluation of phytosanitary conditions of the pomological collections of quince in Lithuania was conducted (Grigaliūnaité, Žilinskaite, \& Radaitienè, 2012). Norin and Rumpunen (2003) concluded that quince does not have significant pests. However, if the areas of quince increase, some of the fungi common in other crops from the family Rosaceae will also attack the Japanese quince. Fungal diseases dominate in Chaenomeles spp., which may cause fruit spots, rotting of fruits, and die-back of shoots and plants (Norin \& Rumpunen, 2003).

Botrytis cinerea, Monilinia fructigena, and Penicillium expansum were detected and identified as causal organisms of fruit rot in quince during the monitoring carried out in Tambov region of Russia from 2010 to 2016 (Федулова, Куклина, \& Каштанова, 2017). B. cinerea, Fusarium spp., and P. expansum as causal agents of fruit rot were detected in Lithuania (Grigaliūnaitè, Žilinskaitè, \& Radaitienė, 2012). From 1998 to 2001, Norin and Rumpunen studied fungi on quince in Sweden. They identified several genera of fungi involved in fruit rots. $B$. cinerea causal agent of grey mould and $P$. expansum were found on young and mature rotten fruits as well as on fruits kept in cold storage. Brown rot caused by M. fructigena, bitter rot caused by Colletotrichum gloeosporioides, and bull's-eye rot caused by Cryptosporiopsis curvispora (teleomorph Neofabraea malicorticis) and Phlyctema vagabunda (teleomorph Neofabraea alba) were 
observed on mature fruits. Several other Penicillium species such as $P$. brevicompactum, $P$. islandicum and $P$. rugulosum were also isolated from mature fruits. Rot caused by Fusarium spp. was found on young fruits (Norin \& Rumpunen, 2003). Fruit rot caused by Diplodia seriata has been reported as a pathogen of quince in Serbia (Vico et al., 2017). Observations of quince in Latvia showed that this crop was damaged by fruit rot, but systematic assessments have not been performed yet.

The aim of this study was to clarify the fruit rot incidence in Japanese quince plantations in Latvia and explore the factors influencing the rot development.

\section{Materials and Methods}

\section{Monitoring sites and meteorological conditions}

The evaluation of diseases in quince fields was carried out in the vegetation period of 2017. Observations were done in eight places that grow quince commercially (Fig. 1). In all of the places observed, quince was grown using the biological management method; the exception was Dobele, where the integrated management method was used.

The most critical periods in the development of fruit rot depending on the environmental conditions are flowering (the middle to end of May), fruit development (June to July) and time closer to harvesting (August). Meteorological conditions in the vegetation period of 2017 mostly differed from the data of long-term observations. In May, June, and July, the mean air temperature and precipitation were below long-term average. In August, when quince fruits reached the beginning of ripening GS 81 (Growth stage (hereinafter GS) in each assessment was determined using the international decimal code scale $\mathrm{BBCH}$ (BiologischeBundesanstalt, Bundessortenamt und CHemistreIndustrie) for pome fruits, the amount of precipitation and air temperature rose above long-term average. The first decade of September or the harvest time of quince was warm and moist. Meteorological conditions in August and the beginning of September created favourable conditions for the development of fruit rot. Information about the meteorological situation in Latvia was sourced from the website of Latvian Environment, Geology and Meteorology Centre. Meteorological data of the 2017 vegetation period in Dobele (Fig. 2) was collected from a stationary meteorological station placed directly in the area of the Institute of Horticulture in Dobele. Meteorological conditions in Dobele were similar to those in other observation places but had some differences. At the end of May, during flowering, the precipitation level was comparatively lower but the mean air temperature was above long-term average. In June, during the beginning of fruit development, precipitation was higher than long-term average but the mean air temperature was moderate, although rose above long-term average.

\section{Evaluation methods of fruit rot}

Assessments of fruit rot incidence started at the beginning of Japanese quince fruit development (GS 71), i.e., on June 15, 2017 and lasted until fruit ripening (GS 87), i.e., September 13, 2017. Hereinafter in the

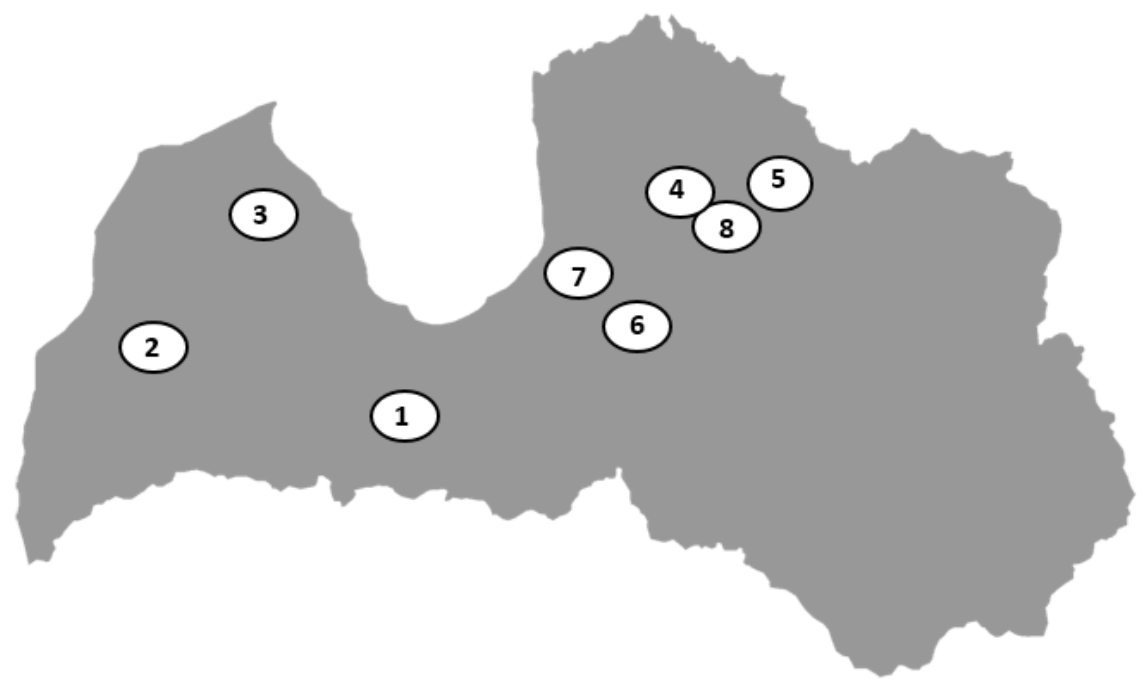

Figure 1. Location of the places observed:

1 - Institute of Horticulture (hereinafter Dobele); 2 - farm 'Mežvidi' (hereinafter Mežvidi); 3 - 'Lubeco' Ltd. (hereinafter Lubeco); 4 - 'Cooperative' Ltd. (hereinafter Cooperative); 5 - farm 'Buliņi' (hereinafter Bulinii); 6 - farm 'Elianda' (hereinafter Elianda); 7 - 'Rāmkalni' Ltd. (hereinafter Rāmkalni); 8 - farm 'Lejaskārkli' (hereinafter Lejaskārkli). 


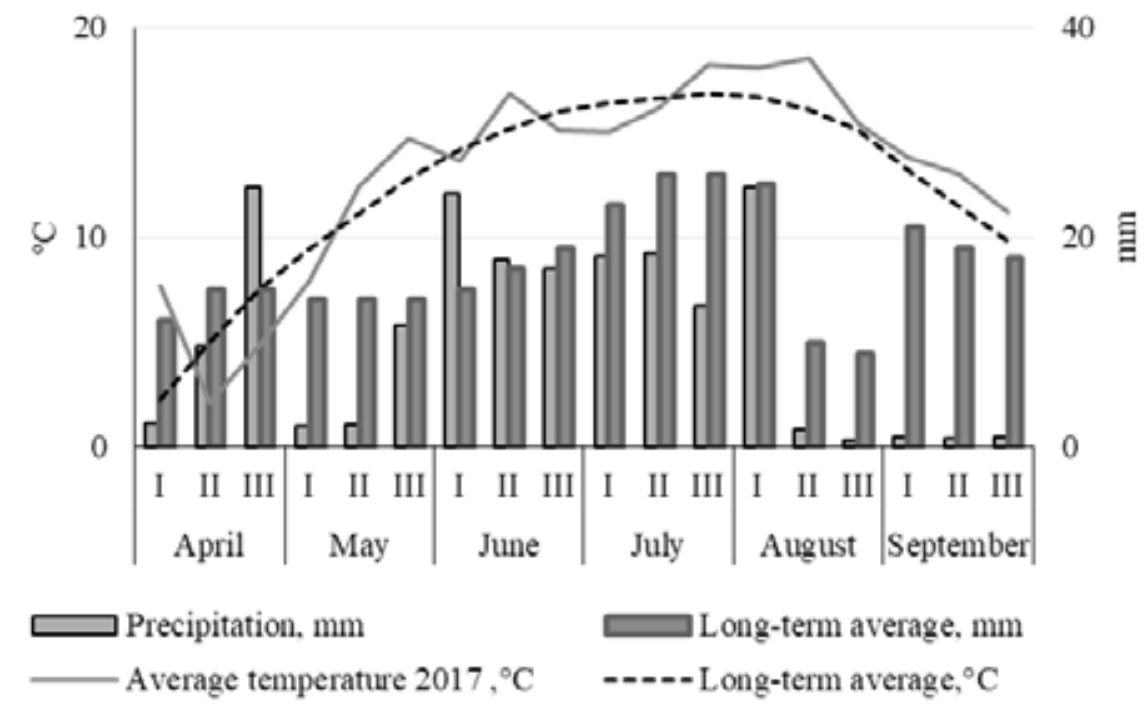

Figure 2. The average temperature and the amount of precipitation in 2017, and long-term data in Dobele.

text the number of assessment times are assigned by ' $\mathrm{n}=\mathrm{x}$ (number of assessments)'. Assessments were conducted once a month or with an interval of 28 days in Mežvidi $(n=4)$, Buliṇi $(n=4)$, Elianda $(n=4)$, Rāmkalni (n=4), and Lejaskārkli $(n=3)$ and twice a month or with an interval of 14 days in Dobele $(n=7)$, Lubeco $(n=7)$, and Cooperative $(n=7)$. Three plantations with different quince cultivars - 'Rondo', 'Rasa' and 'Darius' - were observed in Dobele (each of these $n=7$ ); in other plantations, quince grown from seedlings was observed.

The disease incidence was evaluated diagonally across the field by inspecting 20 randomly selected plants; on each shrub 15 fruits were evaluated. In Cooperative, where the field was too small, evaluation was made in a zigzag pattern throughout the field. The outer edges of the field were avoided. In case there were not enough fruits on the selected shrub, the missing fruits were replaced with fruits from the nearby shrub. In total, 300 fruits were examined in one survey. Fruit rot was recognized visually and rotten fruits recorded in the observation form intended for this purpose.

\section{Statistical processing of data}

The incidence was calculated with the formula:

$$
I=\frac{n}{N} \times 100
$$

where I - Incidence, \%;

$\mathrm{n}$ - number of infected fruits;

$\mathrm{N}-$ all assessed fruits.

For statistical processing of data, the analysis of variance (ANOVA) was used. The significance level of $\alpha=0.05$ was used. For data processing, the programs 'R' (version 3.4.3.) and 'RStudio' were used.

\section{Results and Discussion}

Symptoms of rot

Young fruits of quince from the first to second fruit drop (GS 71-73) turned yellow but did not fall off the plants immediately, which should be typical for this growth stage interval. The first rot signs on these yellow and weakened young fruits were observed. Fruits turned brown, and rot covered all or part of the young fruit.

Fruit remained erect (the underside of fruit and stalk forming a T) until fruits reached half of the final size (GS 74-75), rot development continued and grey mycelium or tan spore sporodochia appeared on rotten fruits in moist conditions. Similar signs have been described also by other authors, for example, Norin and Rumpunen (2003) associated them with gray mould and Fedulova, Kuklina, \& Kashtanova (2017) with brown rot, respectively.

During the sizing process when fruits reached $60-80 \%$ of their characteristic size (GS 76-78), the development of the above-described rot was observed and other symptoms appeared. Brown irregular sunken spots which covered $30-50 \%$ of fruit surface were noticed. Rot-damaged areas were rounded with a noticeable red to purple border in some samples. Norin and Rumpunen (2003) reported that the red border around rot damage could be associated with plant resistance to pathogens.

Up to the next observations, when quince fruits had reached $90 \%$ of their characteristic size and ripening had started (GS 79-80), a large number of rotten fruits had fallen down. Different symptoms of rot, as described before, continued to progress.

During the last times of observations (from the beginning of ripening till the fruits were ripe for picking (GS 81-87), different disease symptoms were found, such as concentric rings in the rotten parts 


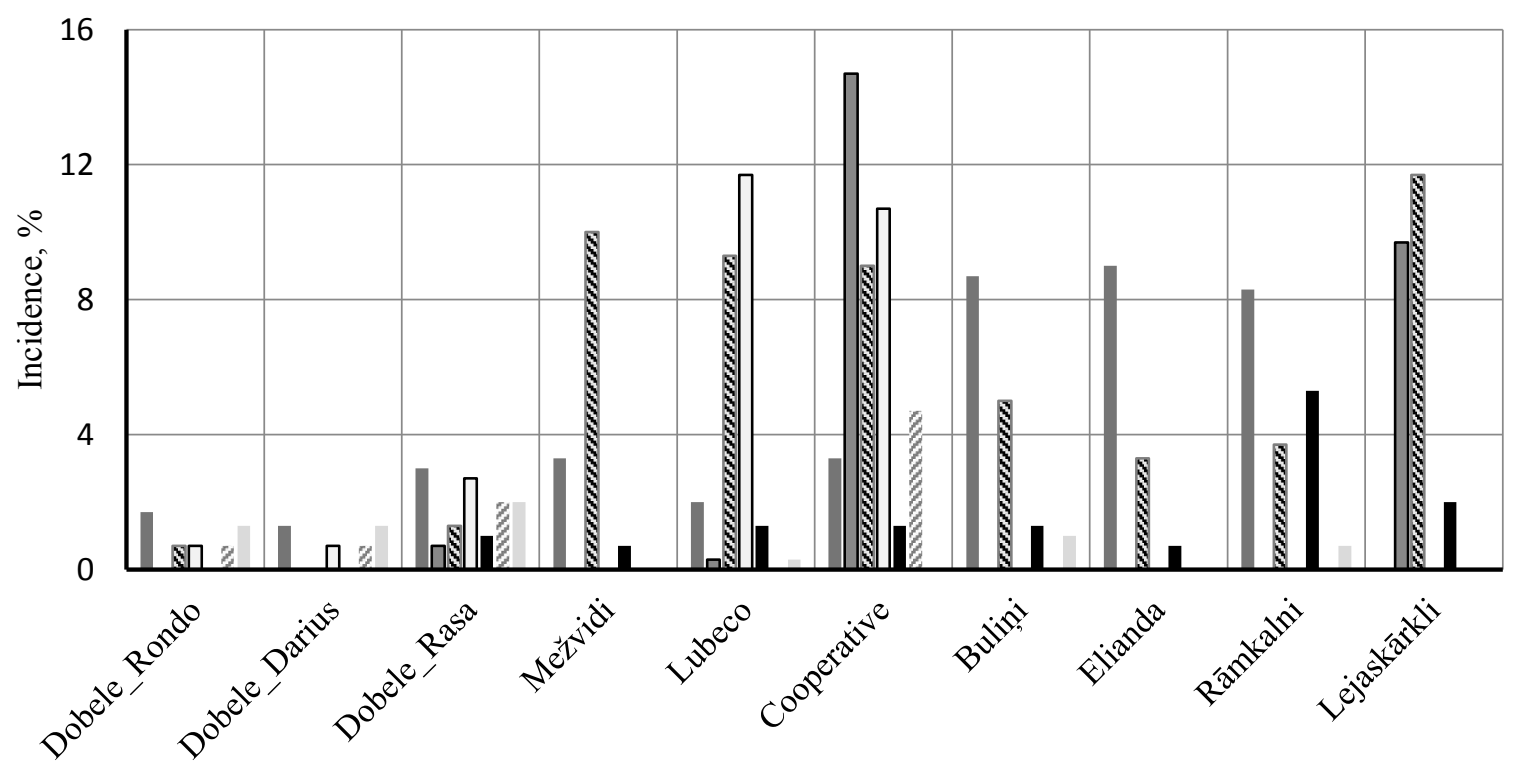

Observed plantations

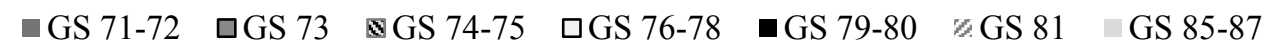

Figure 3. Incidence of fruit rot depending on the plantation at different growth stages of Japanese quince.

of some samples. These symptoms could be a sign of bull's-eye rot caused by Neofabraea species and described by Hortova, Novotny, \& Erban (2014) on apples in the Czech Republic. Fully rotten fruits in this observation period were detected more often than in previous observations.

Symptoms of fruit rot differed depending on meteorological conditions as well as, possibly, also on cultivar and growth stages; therefore, further investigations are required for precise description of symptoms and identification of causal agents.

\section{Incidence of rot}

The first symptoms of rot on young fruits of Japanese quince were observed in all observed plantations in the middle of June (GS 71-72); the incidence of rot fluctuated between $1.3 \%$ and $9.0 \%$ depending on the plantation (Fig. 3).

In the next observations (GS 73), in some plantations (e.g. Dobele Rondo and Dobele Darius), rot was not found on the fruit, which could be explained with the first or second fruit drop when rotten fruits had fallen down and, therefore, could not be included in further assessments. However, incidence of rot mainly in different observation places continued to increase during GS 74-75 and GS 76-78. At this stage, in some plantations (e.g. Mežvidi, Lubeco, Cooperative and Lejaskārkli), rot incidence exceeded $10 \%$, which can be considered an agronomically significant level. Subsequent assessments until fruit maturing showed a decrease in rot incidence: at GS 79-80 it varied from 0 to $5.3 \%$ depending on the location; and at
GS 81 and GS $85-87$ it varied from 0 to $1.3 \%$. This fact can be explained with abundant mass falling of rotten fruits after GS 76-78. A similar situation was described in Sweden, where a large number of rotten young fruits had fallen on the ground. $B$. cinerea infection was recognized as the most important reason for fruit falling (Norin \& Rumpunen, 2003). Further investigations are required to clarify whether fallen infected young fruits affect fruit rot incidence during fruit ripening. No statistically significant differences $(p>0.05)$ in rot incidence among the plantations were found; however, there was a tendency for the incidence of rot in Dobele to be lower than in the plantations of other places. One of its possible reasons is that in Dobele quince cultivars were grown, whereas in all other places quince was grown from seedlings. Also, management methods in Dobele were different and more intensive than in the observation places where organic management was used. This means that quince plants in Dobele received balanced fertilization and were more resistant to unfavourable conditions. Consequently, a hypothesis is proposed that the origin of the planting material and quince growing management are important factors influencing fruit rot incidence.

Mean incidence of fruit rot varied in different growth stages of quince (Fig. 4). Statistically significant differences in fruit rot incidence depending on growth stages $(\mathrm{p}<0.05)$ were found.

A significantly higher incidence of rot was detected at growth stage intervals 74-75 and 76-78 in comparison with later stages of quince development. 


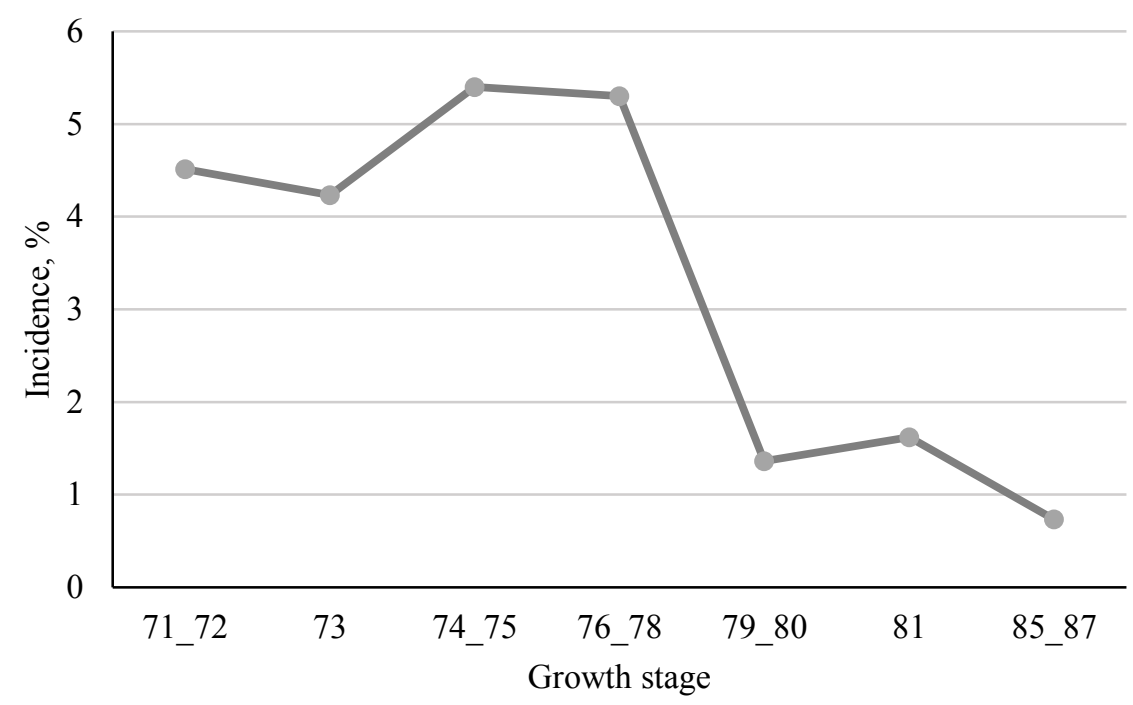

Figure 4. Incidence of fruit rot depending on growth stages of Japanese quince (average data).

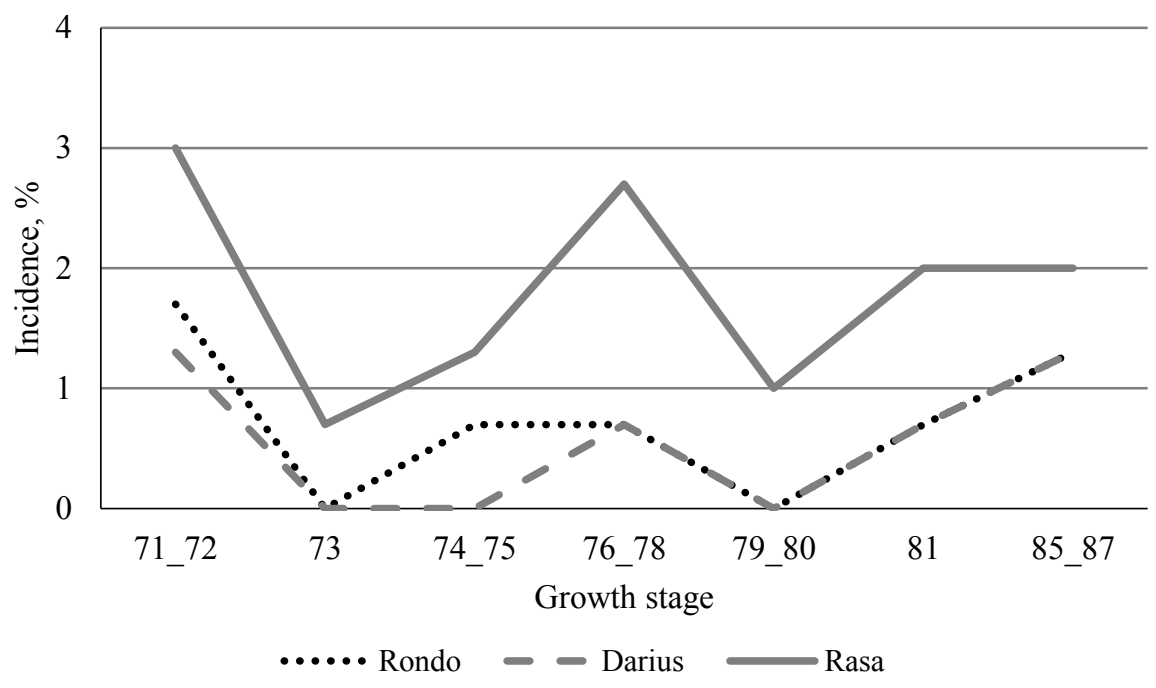

Figure 5. Development of fruit rot incidence depending on quince cultivar in Dobele.

This suggests that young infected fruits identified at GS 71-73 were an important source for further fruit rot development. Furthermore, the time of the significant fruit rot increase coincided with the occurrence of relatively high precipitation and air temperatures. This could mean that weather conditions had an important influence on fruit rot development during the fruit growth. It is considered that precipitation and moderate air temperatures during flowering have an impact on fruit rot development. Quince flowering in Dobele in 2017 was observed from the middle to the end of May. This period was characterized by moderate air temperatures, but precipitation level was low and notably below the long-term data in full flowering, which can explain the comparatively low fruit rot incidence in quince plantations in Dobele. Further investigations are required to clarify whether the remaining fruits and fallen infected young fruits affect fruit rot incidence during fruit ripening.

Studies in Tambov region of Russia also showed differences in the susceptibility of quince cultivars to diseases including fruit rot (Федулова, Куклина, \& Каштанова, 2017). In Dobele, the impact of quince cultivars on rot incidence was studied in the plantations of three cultivars registered in Latvia (Fig. 5 ), and significant differences in fruit rot incidence $(\mathrm{p}<0.05)$ were determined.

Although differences among cultivars were significant, the disease progress curves were similar. After GS 79-80, differences in rot development occurred, and a tendency of a faster increase in rot incidence in 'Rondo' and 'Darius' was observed if compared to cultivar 'Rasa'. This can be explained with differences in the ripening process of cultivars. 
Fruits of 'Rondo' and 'Darius' had a faster and more regular ripening process, but fruits of 'Rasa' ripened unevenly, which had an impact on the development of fruit rot as well.

\section{Conclusions}

1. Fruit rot incidence in Japanese quince varied among the plantations but significant differences were not found. However, there was a tendency that the origin of the planting material and quince growing management importantly influenced fruit rot incidence.

2. Growth stages had a significant impact on fruit rot incidence in Japanese quince during fruit development. The significantly highest fruit rot incidence was detected in the middle of vegetation period when fruits reached $40-80 \%$ (GS 74-78) of their characteristic size.

3. Cultivars of Japanese quince showed different susceptibilities to fruit rot.

4. Further investigations are required to identify the pathogens causing rot in Japanese quince to better explain the biological properties of fruit rot development in quince plantations.

\section{Acknowledgements}

The research was financed by the ERDF project 'Environment-friendly cultivation of emerging commercial fruit crop Japanese quince (Chaenomeles japonica) and waste-free methods of its processing'.

\section{References}

1. Banaś, A., \& Korus, A. (2016). Health-promoting qualities of Japanese quince fruit (Chaenomeles japonica) [Abstract]. Medycyna Rodzinna. 2, 83-85.

2. Baranowska-Bosiacka, I., Bosiacka, B., Rast, J., Gutowska, I., Wolska, J., Rębacz-Maron, ... Chlubek, D. (2017). Macro - and microelement content and other properties of Chaenomeles japonica L. fruit and protective effects of its aqueous extract on hepatocyte metabolism. Biol. Trace Elem. Res. 178(2), 327-337. DOI: 10.1007/s12011-017-0931-4.

3. Fedulova, Y.A., Skripnikova, M.K., \& Mezhenskǐr, V.N. (2009). Biological features and economic value of Japanese quince [Abstract]. Sadovodstvo i Vinogradarstvo. 1, 2-3.

4. Grigaliūnaitè, B., Žilinskaitè, S., \& Radaitienè, D. (2012). Japoninio svarainio (Chaenomeles japonica) fitosanitarinè būklè Vilniaus Universiteto Botanikos sode (Phytosanitary condition of Chaenomeles japonica in Vilnius University Botanical garden). In 8th Annual National Scientific Conference 'Optimization of Ornamental and Garden Plant Assortment, Technologies and Environment': scientific articles, 3(8), 21 March 2012 (pp. 25-29). Mastaiciai: Printing House of Kauno kolegija/University of Applied Sciences. (in Lithuanian).

5. Hortova, B., Novotny, D., \& Erban, T. (2014). Physiological characteristics and pathogenicity of eight Neofabraea isolates from apples in Czechia. Europ. J. Hort. Sci. 79(6), 327-334.

6. Kaufmane, E., Skrivele, M., Rubauskis, E., Strautina, S., Ikase, L., Lacis, ... Priekule, I. (2013). Development of fruit science in Latvia. Proceedings of the Latvian Academy of Sciences, Section B: Natural, Exact, and Applied Sciences, 67(2), 71-83. DOI: 10.2478/prolas-2013-0013.

7. Kauppinen, S., \& Weckman, A. (2002). Japanese quince - a new European fruit crop [Abstract]. Teho, 2002(2), 18-20, 46-47. ISSN: 0355-0567.

8. Ling-Ti, L., Cuizhi, G., Chaoluan, L., Alexander, C., Bartholomew, B., Brach, A.R., ... Spongberg, S.A. (2003). Rosaceae. Flora of China, 9, 46-434. Retrieved January 19, 2018, from: http//flora.huh.harvard. edu/china/mss/volume09/Rosaceae.PDF.

9. Mierina, I., Serzane, R., Strele, M., Moskaluka, J., Seglina, D., \& Jure, M. (2011). Extracts of Japanese quince seeds - potential source of antioxidants. In 6th Baltic Conference on Food Science and Technology FOODBALT-2011. Innovations for food science and production: Conference Proceedings, 5-6 May 2011, (pp. 98-103). Jelgava: Latvia University of Agriculture, Faculty of Food Technology.

10. Ministry of Agriculture of Republic of Latvia. (2016). Lauksaimniecības gada zingojums par 2016. gadu. (Annual Agricultural report for 2016). Retrieved January 17, 2018, from: https://www.zm.gov.lv/ lauksaimnieciba/statiskas-lapas/lauksaimniecibas-gada-zinojumi?nid=531.

11. Nahorska, A., Dzwoniarska, M., \& Thiem, B. (2014). Fruits of Japanese quince (Chaenomeles japonica (Thunb.) Lindl. ex Spach) as a source of bioactive compounds [Abstract]. Postepy Fitoterapii, 4, $239-246$.

12. Norin, I., \& Rumpunen, K. (2003). Pathogens on Japanese quince (Chaenomeles japonica) plants. In: Rumpunen K. (Eds.), Japanese quince - Potential fruit crop for Northern Europe (pp. 37-54). Department of Crop Science, Swedish University of Agricultural Sciences.

13. Panteev, A.V., Batchilo, A.I., \& Grakovich, Z.V. (1995). The breeding of Chaenomeles japonica Lindl. (Japanese quince), Cerasus tomentosa Wall. (felt cherry), and Viburnum opulus L. (snowball tree) in the Republic of Belarus. Acta Hortic. 390, 133-136. DOI: 10.17660/ActaHortic.1995.390.18. 
14. Phipps, J.B., Robertson, K.R., Smith, P.G., \& Rohrer, J.R. (1990). A checklist of the subfamily Maloideae (Rosaceae). Can. J. Bot. 68(10), 2209-2269. DOI: 10.1139/b90-288.

15. Rumpunen, K. (2002). Profitability for Cultivation of Japanese Quince (Chaenomeles japonica). In: J. Whipkey \& A. Janick (Eds.), Trends in new crops and new uses (pp. 181-184). Alexandria: ASHS Press.

16. Vico, I., Žebeljan, A., Vučković, N., Vasić, M., \& Duduk, N. (2017). First Report of Diplodia seriata causing postharvest rot of quince fruit in Serbia. Plant Disease. 101(10), 1823. DOI: 10.1094/PDIS-0417-0484-PDN.

17. Weber, C. (1964). The genus Chaenomeles (Rosaceae). Journal of the Arnold Arboretum. 45(2), 161-205.

18. Федулова, Ю.А., Куклина, А.Г., \& Каштанова, О.А. (2017). Изучение патогенной микофлоры и энтомофауны на культиварах хеномелеса (Chaenomeles lindl.) в Тамбовской области (The study of pathogenic mycoflora and entomofauna on the cultivars of Chanomeles (Chaenomeles lindl.) in the Tambov region. Вестник Мичуринского Государственного Аграрного Университета, 2, 25-30. Retrieved January 17, 2018, from: http://mgau.ru/file_article/vestnik_2_2017.pdf. (in Russian). 